\title{
Current Treatment Strategies in Pulmonary Hypertension Associated with Left Heart Disease
}

\author{
Van N. Selby ${ }^{1} \cdot$ Teresa De Marco $^{1}$
}

Published online: 5 October 2015

(C) Springer International Publishing AG 2015

\begin{abstract}
Pulmonary hypertension (PH) is a common complication of left heart disease (LHD) and is associated with impaired functional capacity and decreased survival. Recent guidelines have proposed a new classification system for PHLHD that is based on the diastolic pulmonary gradient. Despite a sound physiologic basis, subsequent studies have not found a significant correlation between the diastolic pulmonary gradient and meaningful outcomes. Treatment of PH-LHD focuses on optimizing the left heart disease. The use of medications for the treatment of combined post- and pre-capillary PH in left heart disease is controversial. While several small studies have shown hemodynamic or symptomatic improvement, none have been demonstrated to clearly improve long-term outcomes. Large, event-driven trials of PH-LHD are needed to guide the optimal management of this population.
\end{abstract}

Keywords Pulmonary hypertension $\cdot$ Heart failure $\cdot$ Diastolic pulmonary gradient $\cdot$ Heart transplant

\section{Introduction}

Pulmonary hypertension $(\mathrm{PH})$ is a frequent complication of left heart disease (LHD). It is most commonly seen in patients with heart failure (HF), and its presence is associated with

This article is part of the Topical Collection on Thoracic Transplantation

Teresa De Marco

demarco@medicine.ucsf.edu

Van N. Selby

van.selby@ucsf.edu

1 University of California, San Francisco, 505 Parnassus Avenue, Box 0124, San Francisco, CA 94143, USA more severe symptoms, reduced functional capacity, and reduced survival $[1 \bullet, 2,3]$. Pulmonary hypertension associated with LHD is initially caused by passive transmission of elevated left-sided filling pressures. With long-standing pulmonary venous hypertension (post-capillary $\mathrm{PH}$ ) associated with neurohormonal and other mediator upregulation and neurogenic stimuli, some patients will develop pulmonary vasoconstriction with or without vascular remodeling [4]. Identifying post-capillary $\mathrm{PH}$ with a significant pre-capillary component (combined post- and pre-capillary $\mathrm{PH}$; $\mathrm{Cpc}-\mathrm{PH}$ ) is crucial for multiple reasons, including establishing heart transplant candidacy [5] and need for intervening circulatory support at a bridge to transplant.

For those with substantial pre-capillary disease despite maximal treatment of the LHD, there is growing interest in the application of pulmonary arterial hypertension (PAH)specific therapies for PH-LHD. Although promising, this practice is not currently supported by evidence from large, prospective, well-conducted clinical trials. This review will address the epidemiology, current definitions, and therapeutic options for PH-LHD.

\section{Epidemiology}

\section{Prevalence}

The true prevalence of PH-LHD is unknown, with estimates ranging from 25 to $83 \%$ [6-8]. This uncertainty is related to several factors including variations in the definition of PH-LHD used in the literature, heterogeneity of the populations studied, and data that are derived from either large community-based cohorts or tertiary care centers $[3,8,9]$. Many studies have used data based solely on echocardiographic measurements of systolic pulmonary artery pressure 
(sPAP) [6-8]. Estimates of prevalence based on invasive hemodynamics have been published [10], but such studies may be subject to referral bias as sicker patients are more likely to be referred for right heart catheterization (RHC). Regardless of the exact prevalence, PH-LHD is the most common type of $\mathrm{PH}$ encountered in clinical practice $[10,11]$.

PH-LHD is seen in all of the commonly encountered forms of LHD. In a cohort of 244 patients with heart failure and preserved ejection fraction (HFpEF), Lam et al. found that $83 \%$ had PH compared to just $8 \%$ in a control sample of hypertensive patients without HF [8]. Pulmonary hypertension is similarly common among patients with heart failure and reduced ejection fraction (HFrEF). In a study of 1541 patients with LV ejection fraction (EF) $<40 \%$, Miller and colleagues found that $72 \%$ had a mean PA pressure (mPAP) $>25 \mathrm{mmHg}$ and $35 \%$ had a pulmonary vascular resistance (PVR) $\geq 3$ Wood units $(\mathrm{Wu})$ [12]. Pulmonary hypertension is also a common complication of valvular heart disease, with mitral stenosis the most strongly associated. Hart and colleagues found that $73 \%$ of patients with mitral stenosis had $\mathrm{mPAP} \geq 25 \mathrm{mmHg}$ [13]. Pulmonary hypertension is common in patients with other forms of valvular LHD, though less so compared to mitral stenosis. In a study of 1080 patients with severe aortic stenosis referred for AVR, PH was identified in $47 \%$ [14]. In a large multicenter registry of patients with significant mitral regurgitation $23 \%$ of the patients had sPAP $>50 \mathrm{mmHg}$ [15].

\section{Prognostic Implications}

The association between $\mathrm{PH}$ and worse prognosis in patients with LHD is well established. In a cohort of patients referred for endomyocardial biopsy, Cappola and colleagues found that every $5 \mathrm{mmHg}$ increase in the mPAP was associated with a $25 \%$ increase in the risk of death [16]. Among patients with PH-LHD, those with significant pre-capillary disease (Cpc-PH) generally have worse hemodynamics and prognosis. PVR has been a particularly strong predictor of outcomes $[16,17]$.

\section{Diagnostic Approach and Classification of PH-LHD}

Pulmonary hypertension is defined as sustained elevation of the mean PA pressure of $\geq 25 \mathrm{mmHg}$ at rest, as measured by RHC. Pulmonary hypertension can occur due to a variety of causes and is generally categorized according to the system established by the World Health Organization [18]. Pulmonary hypertension due to left heart disease (WHO group 2) is characterized by elevated left-sided filling pressure, most commonly defined as a pulmonary artery wedge pressure (PAWP) $>15 \mathrm{mmHg}$. The left atrial pressure or left ventricular end-diastolic pressure (LVEDP) may be used as appropriate and available, especially if the PAWP accuracy needs confirmation in the absence of mitral valve disease. The importance of a well-performed RHC and careful interpretation of measurements, specifically confirmation of the left-sided filling pressure, cannot be overemphasized [19]. It is imperative to level the transducer at atrial level and to zero to atmospheric pressure. The standard is to measure pressures at endexpiration. Accuracy of the PAWP can be confirmed by measuring oxygen saturation from a sample drawn in the wedge position showing a peripheral capillary oxygen saturation $\left(\mathrm{SpO}_{2}\right)>90 \%$. If the $\mathrm{SpO}_{2}$ is $<90$, then direct left heart pressures should be measured (left ventricular end-diastolic pressure, rarely left atrial pressure). While there are no formal guidelines for right heart catheterization, expert recommendations are available [20]. Data from a well-performed RHC must be incorporated with each patient's clinical presentation and echocardiographic findings to clearly differentiate $\mathrm{PH}-$ LHD from PAH or other causes of pulmonary hypertension. One of the most challenging determinations encountered in the hemodynamic assessment of $\mathrm{PH}$ is differentiating $\mathrm{PAH}$ from PH-HFpEF. Echocardiography is often used as an initial diagnostic test, and an LV EF $<50 \%$ favors PH-LHD. In patients with normal EF, no single echocardiographic finding is specific for PH-LHD. Doppler evidence of diastolic dysfunction can be seen in both PH-LHD and pulmonary vascular disease [21], though more dramatic measures of LV diastolic dysfunction such as elevated tissue-Doppler E/e' ratio, a restrictive transmitral filling pattern, and left atrial enlargement all favor PH-LHD [22-24]. Echocardiography can also be used to estimate PVR. Systolic notching of the RV outflow tract Doppler flow velocity envelope, created by early wave reflection due to stiff pulmonary vasculature, was highly associated with PVR $>3 \mathrm{Wu}$ in one cohort of subjects with $\mathrm{PH}$ [25]. Invasive hemodynamic assessment remains the gold standard for differentiating PH-LHD from PAH. Both volume loading and exercise at the time of RHC have been suggested, though recent evidence suggests exercise may be more sensitive for unmasking hemodynamic abnormalities suggestive of HFpEF [26].

\section{Vasodilator Testing}

In patents with $\mathrm{Cpc}-\mathrm{PH}$, vasodilator testing is used to differentiate those with reversible pre-capillary $\mathrm{PH}$ from those with fixed disease due to pulmonary vascular remodeling. Vasodilator testing is particularly useful in patients undergoing evaluation for heart transplantation to avoid acute donor right heart failure at the time of transplantation which is associated with high mortality up to 3 months post transplant [27]. Patients with Cpc-PH in whom the pre-capillary component (assessed using the transpulmonary gradient (TPG) or PVR) can be effectively reduced with vasodilators have similar posttransplant mortality compared to patients with $\mathrm{PH}[28,29]$. Current guidelines recommend vasodilator testing in all heart 
transplant candidates when $\mathrm{SPAP} \geq 50 \mathrm{mmHg}$ and either $\mathrm{TPG} \geq 15 \mathrm{mmHg}$ or PVR $>3 \mathrm{Wu}[5]$.

Because of the possibility of hemodynamic instability, short-acting vasodilator agents are generally preferred for diagnostic testing. Protocols using nitroprusside, milrinone, prostacyclins, nitric oxide, and nitroglycerin have all been reported [27, 30-32]. After obtaining resting hemodynamics, the vasodilator is initiated and the dose is up-titrated incrementally with regular hemodynamic measurements and close monitoring for the development of hypotension (systolic blood pressure (SBP) $<90 \mathrm{mmHg}$ ) or other evidence of hypoperfusion. Ability to achieve a PVR $<2.5 \mathrm{Wu}$ while maintaining adequate systemic blood pressure $(\mathrm{SBP}>85 \mathrm{mmHg}$ ) identifies patients at lower risk of post-transplant mortality [27]. Close monitoring during titration of vasodilator agents is critical given the potential for adverse effects. By decreasing the pulmonary vascular resistance and increasing transpulmonary blood flow, IV prostacyclins and inhaled nitric oxide may cause an acute increase in the PAWP and precipitate pulmonary edema [33]. For these reasons, nitroprusside is generally the preferred agent for evaluation of reversibility in PH-LHD [1••].

\section{Definitions of PH-LHD}

Classification of PH-LHD primarily distinguishes patients with $\mathrm{PH}$ stemming from elevated left-sided pressures from those with underlying primary pulmonary vascular disease. The distinction has historically been made based on the TPG (mPAP-PAWP) or the PVR. Patients with high TPG or PVR have significant pre-capillary disease and have traditionally been referred to as "out of proportion," "reactive," or "mixed" PH. Most studies have found the development of pre-capillary disease to be associated with a worse prognosis $[12,16]$. Identification of PH-LHD patients with significant precapillary disease becomes particularly important during consideration of heart transplantation. The extent of pulmonary vascular disease is directly correlated to post-transplant survival in this population [34].

A recent PH-LHD consensus paper identified several flaws in the current definition and classification of $\mathrm{PH}-$ LHD, including marked heterogeneity and confusion with the terminology used to describe PAH [35••]. Furthermore, the consensus panel identified physiologic shortcomings of the TPG. The TPG fluctuates with changes in both stroke volume and left atrial pressure [36, 37]. The diastolic pulmonary gradient (DPG; PA diastolic pressure-PAWP) on the other hand is less dependent on these factors. In an initial study Gerges et al. found that DPG was strongly associated with survival and pathologic changes in PH-LHD [38•].

Based on these findings, the World Symposium on Pulmonary Hypertension task force on PH and LHD proposed a new classification and definition for PH-LHD. Those with significant pre-capillary disease as defined by $\mathrm{DPG}>7 \mathrm{mmHg}$ and PAWP $>15 \mathrm{mmHg}$ are referred to as "combined postcapillary and pre-capillary $\mathrm{PH}(\mathrm{Cpc}-\mathrm{PH})$," while those with PAWP $>15 \mathrm{mmHg}$ but DPG $<7 \mathrm{mmHg}$ are referred to as “isolated post-capillary PH (Ipc-PH)"(Fig. 1). Although DPG is based on sound physiologic evidence and promising initial findings, several potential pitfalls related to the DPG have been identified. The diastolic PA pressure is especially prone to factors such as catheter whip [39], and inaccurate measurements related to use of computer-generated measurements or failure to obtain measurements at end-expiration could have particularly dramatic effects on the DPG. Factors such as heart rate [40], hypoxia [41], and sepsis [42] have also been shown to impact the DPG. In subsequent studies the DPG has not been a strong predictor of survival in PHLHD including patients undergoing right heart catheterization for evaluation of unexplained cardiomyopathy [43], heart transplant patients [44], and patients referred for left ventricular assist device (LVAD) implantation [45]. The concept of a purely DPG-based definition of PH-LHD requires further evaluation and validation before widespread adoption can be recommended.

\section{Treatment of PH-LHD}

Goals of therapy in PH-LHD include alleviating patient symptoms, increasing exercise capacity, preventing right ventricular dysfunction, delaying disease progression, and ultimately reducing morbidity and mortality. The primary treatment of PH-LHD is management of the underlying condition [11]. Most often, this involves medical therapy for chronic HF including vasodilators, diuretics, and neurohormonal antagonists.

\section{Repair of Valvular Heart Disease}

When valvular heart disease is the cause of PH-LHD, correction often leads to substantial improvements in PA pressure and or PVR. Mitral valve disease, for example, is associated with elevated left atrial pressure that frequently leads to CpcPH. One series reported severe PH (PVR $>6 \mathrm{Wu}$ ) in $26 \%$ of patients with mitral stenosis [46], and PH is commonly seen in mitral regurgitation as well. In a study of 31 patients with mitral valve disease and SPAP $>50 \mathrm{mmHg}$, surgical correction resulted in a substantial decrease in left atrial pressure and PVR [47].

Pulmonary hypertension is also seen in approximately $30 \%$ of patients with severe aortic stenosis (AS) [48]. A retrospective study of 47 patients with severe AS and severe $\mathrm{PH}$ (peak tricuspid regurgitation velocity $\geq 4 \mathrm{~m} / \mathrm{s}$ by echocardiography) found $80 \%$ mortality in those treated conservatively. Among patients treated with aortic valve replacement, 

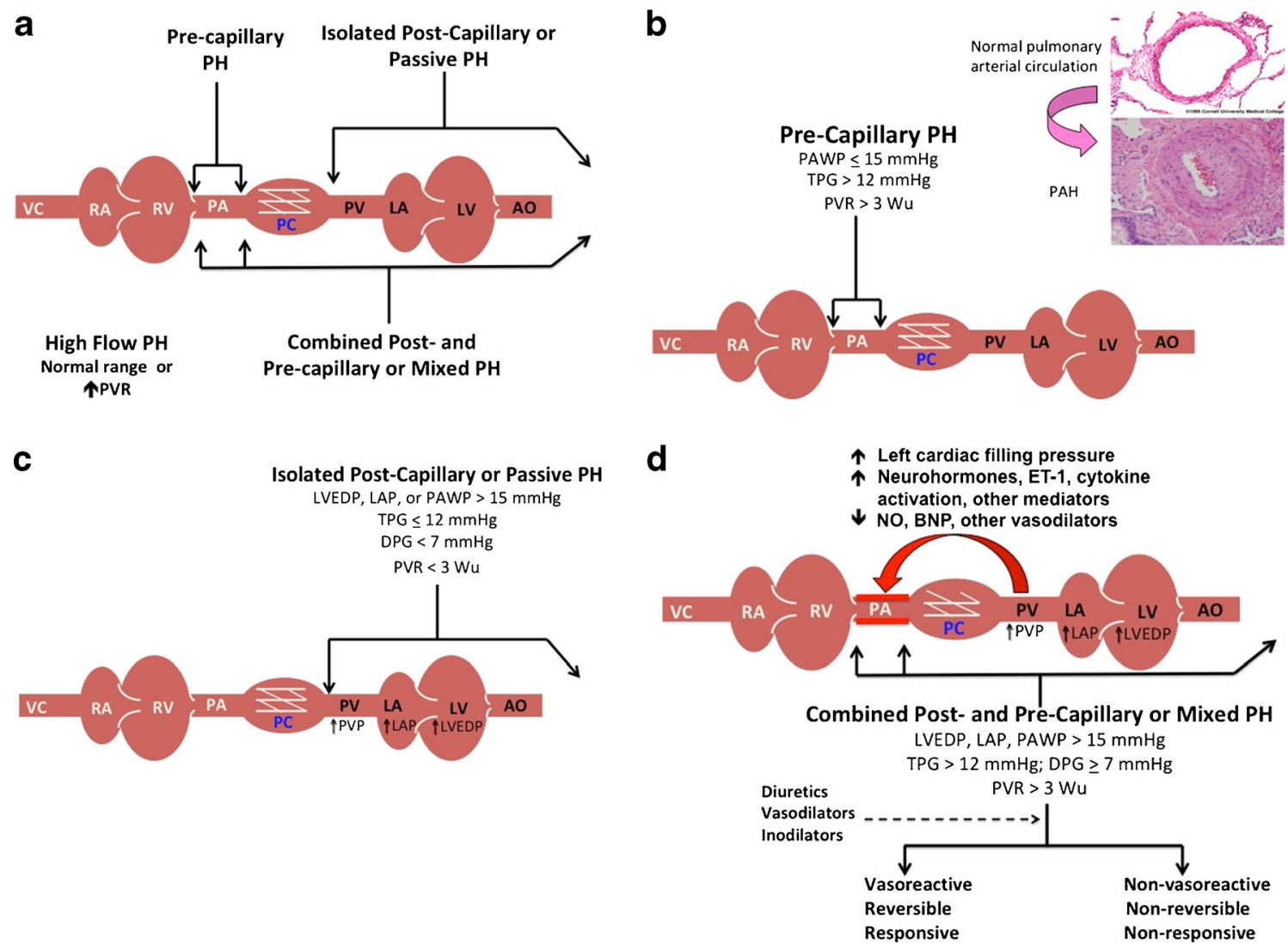

Fig. 1 a Pulmonary hypertension hemodynamic profiles. b Pre-capillary $\mathrm{PH}$. c Isolated post-capillary or passive $\mathrm{PH}$. d Combined post- and precapillary or mixed PH. $A O$ aorta, $B N P$ B-type natriuretic peptide, $D P G$ diastolic pulmonary gradient (diastolic pulmonary artery-pulmonary arterial wedge pressure), ET-1 endothelin-1, $L A$ left atrium, $L A P$ left atrial pressure, $L V$ left ventricle, $L V E D P$ left ventricular end-diastolic pressure, $N O$ nitric oxide, $P A$ pulmonary arterial circulation, $P C$ pulmonary

$16 \%$ had perioperative death, though among operative survivors, there was no difference in long-term survival compared to expected survival from life tables. Therefore, despite the increased operative risk, the authors conclude the long-term benefits of AVR outweigh the risks for patients with severe PH associated with AS [49]. Similarly, in patients referred for transcatheter aortic valve replacement (TAVR), PH is common, improves after correction of AS, and is associated with increased periprocedural risk $[50,51]$.

\section{Left Ventricular Assist Device Implantation}

Irreversible pulmonary hypertension is a contraindication to heart transplant. In patients with advanced heart failure complicated by significant Cpc-PH who would otherwise be candidates for heart transplant, LVAD implantation can be used to decrease left ventricular filling pressures and thereby allow pulmonary vascular remodeling and reduction of pulmonary arterial pressures. The use of LVAD has been shown to

capillary network, $P A W P$ pulmonary arterial wedge pressure, $P H$ pulmonary hypertension, $P V$ pulmonary veins, $P V P$ pulmonary venous pressure, $P V R$ pulmonary vascular resistance (mean $\mathrm{PAP}-\mathrm{PAWP} /$ cardiac output), $R A$ right atrium, $R V$ right ventricle, $T P G$ transpulmonary gradient (mean PAP-PAWP), $W u$ Wood unit. Courtesy International Society for Heart and Lung Transplantation, reproduced with permission

improve both the mean PA pressure and PVR over weeks to months regardless of the specific type of LVAD used [52-57] (Table 1). In a study of 35 patients with fixed pulmonary hypertension and PVR $>3.5 \mathrm{Wu}$, Zimpfer et al. found that mean PVR decreased from 5.1 to $2.0 \mathrm{Wu}$ at 6 weeks and mPAP decreased from 44.0 to $18.4 \mathrm{mmHg}$, with $69 \%$ of patients able to proceed to successful heart transplant [52]. In patients bridged with an LVAD, most authors have found that post-heart transplant survival is similar in patients with and without pre-LVAD pulmonary hypertension $[55,56]$, though these are small studies that may be underpowered to detect significant differences.

\section{Pharmacologic Therapy for PH-LHD}

Clear epidemiologic evidence demonstrating an association between development of PH and decreased survival in patients with LHD has lead to multiple trials evaluating the 
Table 1 Selected studies of ventricular assist device for PH-LHD

\begin{tabular}{|c|c|c|c|c|c|c|}
\hline Author and year & Number & Design/Population & LVAD model & PVR or PVRI & mPAP & Outcome \\
\hline \multirow[t]{2}{*}{ Zimpfer, 2007} & \multirow[t]{2}{*}{35} & \multirow[t]{2}{*}{ Fixed PH, PVR $>3.5 \mathrm{Wu}$} & MicroMed DuraHeart & $\begin{array}{l}\text { Pre, } 5.1 \pm 2.6 \\
3 \text { days, } 2.9 \pm 1.3\end{array}$ & $\begin{array}{l}\text { Pre, } 44.0 \pm 6.2 \\
3 \text { days, } 28.6 \pm 7.3\end{array}$ & \multirow{2}{*}{$\begin{array}{l}\text { Successful OHT in } 24 \\
(69 \%) \text {, on VAD } \\
210 \pm 83 \text { days } \\
\text { 1-year survival post-OHT } \\
95 \%\end{array}$} \\
\hline & & & Novacor & 6 weeks, $2.0 \pm 0.8$ & 6 weeks, $18.4 \pm 4.3$ & \\
\hline Haft, 2007 & 34 & $\begin{array}{l}\text { Indication for LVAD, } \\
3 \text { months follow-up }\end{array}$ & \multicolumn{3}{|c|}{$\begin{array}{l}\cdot \mathrm{HM} \text { I (16), mPAP } \downarrow 37 \pm 8 \text { to } 20 \pm 8 \mathrm{mmHg} \\
\cdot \mathrm{HM} \text { II (18), mPAP } \downarrow 35 \pm 9 \text { to } 20 \pm 6 \mathrm{mmHg} \\
\text { - } \mathrm{CI} \uparrow, \mathrm{PVRI} \downarrow\end{array}$} & $\begin{array}{l}\text { Exercise capacity similar } \\
\text { between device groups; } \\
\text { Echo indices better with } \\
\text { XVE }\end{array}$ \\
\hline Patel, 2008 & 77 & $\begin{array}{l}\text { Retrospective comparison } \\
\text { of post-VAD RV failure } \\
\text { at } 1,3 \text {, and } 6 \text { months }\end{array}$ & \multicolumn{3}{|c|}{$\begin{array}{l}\cdot \text { HM I (43), no significant change in PVRI or mPAP } \\
\text { - HM II (34), } \downarrow \text { mPAP } \downarrow \text { at } 1,3,6 \text { months; } \\
\text { PVRI } \downarrow \text { at } 1 \text { month }\end{array}$} & $\begin{array}{l}\text { Similar incidence of RV } \\
\text { dysfunction between } \\
\text { devices } \\
\text { Fewer HM II patients required } \\
\text { RVAD/inotrope support }\end{array}$ \\
\hline $\begin{array}{l}\text { Torre-Amione, } \\
2010\end{array}$ & 9 & $\begin{array}{l}\text { Retrospective: } \\
\text { TPG }>15 \mathrm{mmHg}\end{array}$ & $\begin{array}{l}\text { Pulsatile (2) } \\
\text { Axial flow (7) }\end{array}$ & \multicolumn{2}{|c|}{$\begin{array}{l}\cdot \text { HM I ( } 43) \text {, no significant change } \\
\text { in PVRI, mPAP } \\
\cdot \text { HM II ( } 34), \text { mPAP } \downarrow \text { at } 1,3 \text {, } \\
\quad 6 \text { months; } \\
\text { PVRI } \downarrow \text { at } 1 \text { month }\end{array}$} & $\begin{array}{l}\text { No difference in } 1 \text {-year } \\
\text { survival for patients with } \\
\text { pre-VAD TPG }>15 \text { vs. } \\
\text { TPG }<15\end{array}$ \\
\hline Alba, 2010 & 54 & $\begin{array}{l}\text { Retrospective comparison } \\
\text { of LVAD patients with } \\
\text { vs. without fixed PH }\end{array}$ & $\begin{array}{l}\text { HM XVE } \\
\text { HM II } \\
\text { Novacor }\end{array}$ & \multicolumn{2}{|c|}{$\begin{array}{l}\text { Fixed PH group: } \\
\cdot \text { sPAP } \downarrow \text { from } 56 \pm 8 \text { to } 31 \pm 8\end{array}$} & $\begin{array}{l}\text { No difference in post- } \\
\text { transplant RV failure } \\
\text { between patients with and } \\
\text { without fixed PH }\end{array}$ \\
\hline Gupta, 2014 & 35 & $\begin{array}{l}\text { Retrospective analysis } \\
\text { of consecutive LVAD } \\
\text { patients, RHC performed } \\
\text { pre-LVAD, and } \\
100.7 \pm 61.4 \text { post-LVAD }\end{array}$ & HVAD & $\begin{array}{l}\text { Pre, } 3.7 \pm 2.4 \\
\text { Post, } 2.2 \pm 1.1\end{array}$ & $\begin{array}{l}\text { Pre, } 38.8 \pm 7.7 \\
\text { Post, } 22.9 \pm 7.7\end{array}$ & $\begin{array}{l}36 \% \text { developed post-VAD } \\
\text { RV failure. RV failure } \\
\text { associated with worse } \\
\text { survival }\end{array}$ \\
\hline
\end{tabular}

$C I$ cardiac index, HM HeartMate, HVAD HeartWare continuous-flow LVAD, $m P A P$ mean pulmonary arterial pressure, $P V R$ pulmonary vascular resistance, $P V R I$ pulmonary vascular resistance index, $O H T$ orthotopic heart transplantation, $P H$ pulmonary hypertension, $R H C$ right heart catheterization, $R V$ right ventricle, $T P G$ transpulmonary gradient

effects of drugs used primarily for PAH in PH-LHD. To date, no therapy targeting Cpc-PH has been shown to improve outcomes in this population, and in some cases there even been signals for adverse outcomes. Table 2 summarizes the key clinical trials of PH therapies for PH-LHD.

\section{Prostacyclins}

Continuously infused epoprostenol is a pulmonary and systemic vasodilator with antiplatelet effects and commonly used in the treatment of advanced PAH. Early studies in HFrEF found acute reduction in the PAWP, PVR, and systemic vascular resistance (SVR), with associated increase in cardiac output (CO). These findings lead to the Flolan International Randomized Survival Trial (FIRST), which randomized 471 patients with New York Heart Association Functional Class (NYHA) class IIIB or IV HFrEF to epoprostenol or standard care [58]. Although subjects randomized to epoprostenol experienced significant hemodynamic improvement, the trial was stopped early due to a strong trend toward decreased survival in the epoprostenol arm.

\section{Endothelin Receptor Antagonists}

Endothelin is a potent vasoconstrictor and a primary mediator of both groups 1 and $2 \mathrm{PH}$. Endothelin receptor antagonists (ERAs) induce vasorelaxation as well as antifibrotic, antiproliferative, and anti-inflammatory effects. They are commonly used in the treatment of group I PH. Initial studies of ERAs in HFrEF suggested an early hemodynamic improvement [59] and prompted larger clinical studies in patients with HF. Unfortunately, multiple clinical trials of various ERAs including bosentan, darusentan, enrasentan, sitaxsentan, and tezosentan have all failed to show improvement in clinical outcomes among patients with HFrEF [60-63]. The MELODY-1 trial (NCT8017311) is currently randomizing patients with left ventricular dysfunction and $\mathrm{Cpc}-\mathrm{PH}$ to macitentan vs. placebo. This phase 2 trial is the first to specifically target patients meeting criteria for $\mathrm{Cpc}-\mathrm{PH}$. Endothelin receptor antagonists have not been well evaluated in PH-LHD due to etiologies other than HFrEF; however, there is no physiologic reason to suspect better outcomes than what was observed in HFrEF. At this time there is no clear role for ERAs in the management of PH-LHD. 
Table 2 Selected randomized, controlled trials of pulmonary vasodilators in LHD

\begin{tabular}{|c|c|c|c|c|}
\hline Drug/Trial & Patients & Design & $1^{\circ}$ Endpoint & Results \\
\hline $\begin{array}{l}\text { Epoprostenol } \\
\text { FIRST (1997) }\end{array}$ & $\begin{array}{l}\text { NYHA IIIB/IV, EF }<25 \% \\
n=471\end{array}$ & $\begin{array}{l}\text { IV epoprostenol } \\
\mathrm{mPA}>25 \mathrm{mmHg}(\mathrm{RHC}) \\
\text { F/u }>1 \text { year }\end{array}$ & Mortality & $\begin{array}{l}\text { Terminated early due to } \\
\text { increased mortality }\end{array}$ \\
\hline $\begin{array}{l}\text { Bosentan } \\
\text { REACH-1 } \\
(2005)\end{array}$ & $\begin{array}{l}\text { NYHA III/IV, EF }<35 \% \text {, } \\
6 \mathrm{MWT}<375 \mathrm{~m} \\
n=370\end{array}$ & F/u 6 months & Change in clinical status & $\begin{array}{l}\text { Terminated early due to } \\
\text { LFTs and edema }\end{array}$ \\
\hline $\begin{array}{l}\text { Bosentan } \\
\text { ENABLE } \\
\text { (unpublished, 2002) }\end{array}$ & $\begin{array}{l}\text { NYHA IIIB/IV } \\
\mathrm{EF}<35 \% \\
n=1613\end{array}$ & F/u 18 months & Mortality + HF hospitalization & $\begin{array}{l}\text { No benefit } \\
\text { Concern for increased HF } \\
\quad \text { hospitalization }\end{array}$ \\
\hline $\begin{array}{l}\text { Tezosentan } \\
\text { VERITAS } \\
(2007)\end{array}$ & $\begin{array}{l}\text { Admitted HF } \\
\text { Mean EF } 29 \% \\
n=1448\end{array}$ & $\begin{array}{l}\text { IV tezosentan } \\
\text { F/u } 1 \text { week }\end{array}$ & Mortality+worsening HF & $\begin{array}{l}\text { No benefit } \\
\text { No difference in dyspnea }\end{array}$ \\
\hline $\begin{array}{l}\text { Darusentan } \\
\text { HEAT-1 } \\
(2002)\end{array}$ & $\begin{array}{l}\text { NYHA III, EF }<35 \% \text {, } \\
\text { PAWP }>12 \mathrm{mmHg} \text {, } \\
\text { CI }<2.6 \mathrm{~L} / \mathrm{min} / \mathrm{m}^{2} \\
N=179\end{array}$ & $\begin{array}{l}\text { Dose-ranging } \\
\text { F/u } 3 \text { weeks }\end{array}$ & Change in PAWP and CI & $\begin{array}{l}\text { Increased CI and decreased } \\
\text { SVR, with no significant } \\
\text { change in mPAP, PVR, or } \\
\text { PAWP. Increased risk of } \\
\text { worsening HF at higher } \\
\text { doses }\end{array}$ \\
\hline Darusentan & NYHA II-IV & Dose-ranging & LV remodeling (MRI) & No benefit \\
\hline $\begin{array}{l}\text { EARTH-2 } \\
(2004)\end{array}$ & $\begin{array}{l}\mathrm{EF}<35 \% \\
n=642\end{array}$ & F/u 6 months & Clinical events & \\
\hline $\begin{array}{l}\text { Macitentan } \\
\text { MELODY-1 } \\
\text { (NCT8017311) }\end{array}$ & LV dysfunction, Cpc-PH & & $\begin{array}{l}\text { Fluid retention+worsening } \\
\text { NYHA functional class }\end{array}$ & Enrolling \\
\hline $\begin{array}{l}\text { Tadalafil } \\
\text { PITCH-HF } \\
\text { (NCT01910389) }\end{array}$ & $\begin{array}{l}\mathrm{EF}<40 \% \\
\mathrm{sPAP}>40 \mathrm{mmHg} \\
n=2102\end{array}$ & F/u 54 months & Time to CV death or HF hosp & $\begin{array}{l}\text { Suspended; did not meet } \\
\text { enrollment milestones }\end{array}$ \\
\hline $\begin{array}{l}\text { Sildenafil } \\
\text { SilHF } \\
\text { (NCT01616381) }\end{array}$ & $\begin{array}{l}\mathrm{EF}<40 \% \\
\mathrm{sPAP}>40 \mathrm{mmHg} \\
n=210\end{array}$ & F/u 24 weeks & Global assessment, 6MWT & Enrolling \\
\hline $\begin{array}{l}\text { Sildenafil } \\
\text { RELAX (2013) }\end{array}$ & $\begin{array}{l}\text { NYHA II-IV } \\
\text { EF }>50 \% n=216\end{array}$ & $\begin{array}{l}\text { Mean } \mathrm{sPAP}=41 \mathrm{mmHg} \\
\quad \text { (no enrollment criteria } \\
\text { related to PA pressure); } \\
\mathrm{F} / \mathrm{u} 26 \text { weeks }\end{array}$ & Peak oxygen consumption & $\begin{array}{l}\text { No benefit in } 1^{\circ} \text { or } 2^{\circ} \\
\text { endpoints }\end{array}$ \\
\hline $\begin{array}{l}\text { Riociguat } \\
\text { LEPHT (2013) }\end{array}$ & $\begin{array}{l}\text { NYHA II-IV } \\
\mathrm{EF}<40 \% n=201\end{array}$ & $\begin{array}{l}\text { Dose-ranging } \\
\text { mPAP }>25 \mathrm{mmHg}(\mathrm{RHC}) \\
\text { F/u } 16 \text { weeks }\end{array}$ & Mean PAP & $\begin{array}{l}1^{\circ} \text { not met } \\
\text { Improved MLWHF } \\
\uparrow C I \& \text { SV } \\
\downarrow \text { PVR \& SVR }\end{array}$ \\
\hline
\end{tabular}

$6 M W T$ six-minute walk test, $C I$ cardiac index, $C V$ cardiovascular, $E F$ ejection fraction, $F / u$ follow-up $L F T s$ liver function tests, $m P A P$ mean pulmonary artery pressure, NYHA New York Heart Association Functional Class, $P C W P$ pulmonary artery wedge pressure, $P V R$ pulmonary vascular resistance, $R H C$ right heart catheterization, $S P A P$ systolic pulmonary arterial pressure, $S V$ stroke volume, $S V R$ systemic vascular resistance. Adapted from International Society of Heart and Lung Transplantation with permission

\section{Phosphodiesterase Inhibitors}

Phophodiesterase-5 (PDE-5) inhibitors increase cGMP and improve both hemodynamics and functional capacity in PAH [64]. The acute effects of sildenafil administration in patients with PH-HFrEF include selective pulmonary arterial vasodilation with a decrease in pulmonary arterial pressure and PVR, accompanied by an increase in cardiac index [65]. In a 12-week study of patients with HFrEF and elevated PVR, sildenafil at a dose of 25 to $75 \mathrm{mg}$ TID decreased PVR and TPG while increasing CO with no effect on PAWP. This was associated with improved functional capacity at 12 weeks
[66]. This and other early studies lead to the design of the Phosphodiesterase Type 5 Inhibition With Tadalafil Changes Outcomes in Heart Failure (PITCH-HF) trial, a large multicenter study powered to evaluate the effect of PDE-5 inhibition on survival and hospitalizations in HFrEF. Unfortunately, this very important trial was terminated early due to inadequate enrollment. The Sildenafil versus Placebo in Chronic Heart Failure (SilHF) trial is currently enrolling patients with NYHA classes II-III heart failure, left ventricular ejection fraction (LVEF) $<40 \%$, and sPAP $>40 \mathrm{mmHg}$. Two hundred ten subjects will be randomized to sildenafil $40 \mathrm{mg}$ TID vs. placebo [67]. The primary endpoints are patient global 
assessment and six-minute walk distance rather than morbidity and mortality.

Similar benefits have been reported in patients HFpEF. In a study by Guazzi et al., 44 patients with HFpEF and PASP $>40 \mathrm{mmHg}$ were randomized to sildenafil $50 \mathrm{mg}$ TID or placebo [68]. At 6 months, subjects randomized to sildenafil had a significant improvement in mean PA pressure, right ventricular function, right atrial pressure, pulmonary vascular resistance, pulmonary artery wedge pressure (PCWP), and cardiac index. These improvements were maintained at 12 months. The multicenter PhosphdiesteRasE-5 Inhibition to Improve CLinical Status and EXercise Capacity in Diastolic Heart Failure (RELAX) Trial randomized 216 subjects with heart failure and LVEF $>50 \%$ to sildenafil vs. placebo [69•]. Treatment with sildenafil did not improve exercise capacity or clinical status. A key aspect of RELAX is the lack of enrollment criteria related to PA pressures. Therefore, RELAX should be considered a trial of sildenafil in HFpEF, not PH-LHD.

Despite a wealth of data demonstrating hemodynamic and clinical improvement from treatment of PH-LHD with PDE-5 inhibitors, no large-scale studies addressing this specific question have been completed. Until such a trial is performed, clinical guidelines are unlikely to recommend routine use of PDE-5 inhibitors in PH-LHD. That said, there may be particular clinical scenarios in which off-label use of PDE-5 inhibitors is reasonable in the management of PH-LHD. In an openlabel study of patients undergoing heart transplant evaluation, those with persistently elevated PVR after LVAD implantation who were treated with sildenafil (titrated to an average dose of $51.9 \mathrm{mg}$ TID) saw significantly greater reduction in PVR compared to those not receiving sildenafil, with an average improvement from 5.87 to $2.96 \mathrm{Wu}$ [70]. Similarly, in a study of ten patients with post-LVAD PH and failure to wean from inhaled nitric oxide or inotropic support, sildenafil was associated with a rapid decrease in SPAP and successful weaning from support [71]. Table 3 summarizes key findings from studies evaluating the effects of sildenafil in LVAD patients. Clinical applications such as this one are unlikely to be evaluated in large-scale studies, and given the current evidence many centers have successfully used PDE-5 inhibitors in the management of patients with severe $\mathrm{PH}$ requiring LVAD as bridge to heart transplantation [70].

\section{Soluble Guanylate Cyclase Stimulators}

Riociguat is a soluble guanylate cyclase (sGC) stimulator with vasodilatory, antifibrotic, and anti-inflammatory effects [72] that was recently shown to improve outcomes in subjects with both PAH [73] and chronic thromboembolic pulmonary hypertension [74]. The DILATE trial randomized 39 subjects with clinically stable HFpEF ( $\mathrm{EF}>50 \%$ ), mean PA pressure $\geq 25 \mathrm{mmHg}$, and PCWP $>15 \mathrm{mmHg}$ to placebo or riociguat $(0.5,1$, or $2 \mathrm{mg})$ [75]. The primary outcome was the peak decrease in mean PA pressure from baseline up to $6 \mathrm{~h}$. There was no significant change in peak decrease with riociguat vs. placebo. There were improvements in several secondary endpoints including stroke volume and right ventricular enddiastolic area.

The Left Ventricular Systolic Dysfunction Associated with Pulmonary Hypertension Riociguat Trial (LEPHT) randomized 201 subjects with group $2 \mathrm{PH}$ and HFrEF to riociguat or placebo [76]. There was no difference in the primary endpoint of mPAP. However, both cardiac index and stroke volume index increased in the riociguat group (with no change in heart rate or blood pressure), along with decreases in both SVR and PVR as well as improvement in quality of life. Although the evidence base supporting riociguat in PH-LHD is sparse, initial findings have been encouraging.

Table 3 Studies of PDE-5 inhibitors for treatment of persistent PH after LVAD

\begin{tabular}{|c|c|c|c|}
\hline Author and year & Number & Design/Population & Findings \\
\hline Klodell, 2007 & 10 & $\begin{array}{l}\text { - Retrospective review } \\
\text { - Post-LVAD PH } \\
\text { - Sildenafil given at the discretion of the primary } \\
\text { team for failure to wean iNO or inotropic support }\end{array}$ & $\begin{array}{l}\text { - sPAP decreased within } 90 \text { min of administration }(p<0.05) \\
\text { - No change in SBP, MAP, SVR, or HR } \\
\text { - All } 8 \text { patients weaned from iNO within } 12 \mathrm{~h} \\
\text { - All } 10 \text { patients weaned from inotropic support within } 72 \mathrm{~h}\end{array}$ \\
\hline Tedford, 2008 & 138 & $\begin{array}{l}\text { - } 58 \text { patients with no decrease in PVR } 1-2 \text { weeks } \\
\text { post LVAD } \\
\text { - } 26 \text { consecutive patients received sildenafil } \\
\text { (mean dose } 52 \mathrm{mg} \text { TID) } \\
\text { - } 32 \text { controls }\end{array}$ & $\begin{array}{l}\text { - Sildenafil group (12-15 weeks post-LVAD): } \\
\text { PVR decreased by } 5.87+1.9 \text { to } 2.96+0.92 \mathrm{Wu}^{*} \\
\text { mPAP decreased by } 36.5+24.3 \text { to } 24.3+3.6 \mathrm{mmHg} \text { * } \\
\text { - PVR was significantly lower in sildenafil vs. control groups } \\
\text { - Sildenafil resulted in improved RV function (dP/dT; TAPSE) } \\
\text { vs. control }\end{array}$ \\
\hline
\end{tabular}

$H R$ heart rate, $i N O$ inhaled nitric oxide, $S B P$ systolic blood pressure, TAPSE tricuspid annular plane systolic excursion

$* p<0.01$ 


\section{Conclusions}

The last 10 years have seen increased recognition of PH-LHD as a contributor to poor outcomes and a potential target for therapy. New definitions and terminology, particularly the emphasis on the DPG, reflect an improved understanding of the underlying pathophysiology of PH-LHD. However, further evaluation of the DPG and other novel hemodynamic parameters will help refine our definitions and classification of $\mathrm{PH}$ LHD. In patients with persistent PH despite optimization of left-sided pressures, therapy targeting the pulmonary vasculature is promising, though in the absence of supporting data from large-scale clinical trials this practice remains off-label and best reserved for select clinical scenarios. Hopefully, large clinical trials will help clarify the role of $\mathrm{PH}$-specific therapies and identify the patients most likely to benefit from treatment with these agents.

\section{Compliance with Ethics Guidelines}

Conflict of Interest Van N. Selby declares that he has no conflict of interest.

Teresa De Marco reports personal fees from Actelion, Gilead, Boston Scientific, Gambro, and Cardikinetics. She also reports grants from Pfizer, United Therapeutics, Reata, and United Therapeutics.

Human and Animal Rights and Informed Consent This article does not contain any studies with human or animal subjects performed by any of the authors.

\section{References}

Papers of particular interest, published recently, have been highlighted as:

- Of importance

•- Of major importance

1.• Fang JC, DeMarco T, Givertz MM, et al. World Health Organization Pulmonary Hypertension group 2: pulmonary hypertension due to left heart disease in the adult-a summary statement from the Pulmonary Hypertension Council of the International Society for Heart and Lung Transplantation. J Heart Lung Transpl Off Publ Int Soc Heart Transpl. 2012;31:913-33. Comprehensive review of the pathophysiology, classification, and clinical trials in PH-LHD.

2. Guazzi M, Borlaug BA. Pulmonary hypertension due to left heart disease. Circulation. 2012;126:975-90.

3. Ghio S, Gavazzi A, Campana C, et al. Independent and additive prognostic value of right ventricular systolic function and pulmonary artery pressure in patients with chronic heart failure. J Am Coll Cardiol. 2001;37:183-8

4. Moraes DL, Colucci WS, Givertz MM. Secondary pulmonary hypertension in chronic heart failure: the role of the endothelium in pathophysiology and management. Circulation. 2000;102:1718-23.

5. Mehra MR, Kobashigawa J, Starling R, et al. Listing criteria for heart transplantation: International Society for Heart and Lung
Transplantation guidelines for the care of cardiac transplant candidates-2006. J Heart Lung Transpl Off Publ Int Soc Heart Transpl. 2006;25:1024-42.

6. Damy T, Goode KM, Kallvikbacka-Bennett A, et al. Determinants and prognostic value of pulmonary arterial pressure in patients with chronic heart failure. Eur Heart J. 2010;31:2280-90.

7. Bursi F, Weston SA, Redfield MM, et al. Systolic and diastolic heart failure in the community. JAMA J Am Med Assoc. 2006;296: 2209-16.

8. Lam CSP, Roger VL, Rodeheffer RJ, Borlaug BA, Enders FT, Redfield MM. Pulmonary hypertension in heart failure with preserved ejection fraction: a community-based study. J Am Coll Cardiol. 2009;53:1119-26.

9. Lam CSP, Borlaug BA, Kane GC, Enders FT, Rodeheffer RJ, Redfield MM. Age-associated increases in pulmonary artery systolic pressure in the general population. Circulation. 2009;119: 2663-70.

10. Robbins IM, Newman JH, Johnson RF, et al. Association of the metabolic syndrome with pulmonary venous hypertension. Chest. 2009;136:31-6.

11. Galiè N, Hoeper MM, Humbert M, et al. Guidelines for the diagnosis and treatment of pulmonary hypertension: the Task Force for the Diagnosis and Treatment of Pulmonary Hypertension of the European Society of Cardiology (ESC) and the European Respiratory Society (ERS), endorsed by the International Society of Heart and Lung Transplantation (ISHLT). Eur Heart J. 2009;30: 2493-537.

12. Miller WL, Grill DE, Borlaug BA. Clinical features, hemodynamics, and outcomes of pulmonary hypertension due to chronic heart failure with reduced ejection fraction: pulmonary hypertension and heart failure. JACC Heart Fail. 2013;1:290-9.

13. Hart SA, Krasuski RA, Wang A, Kisslo K, Harrison JK, Bashore TM. Pulmonary hypertension and elevated transpulmonary gradient in patients with mitral stenosis. J Heart Valve Dis. 2010;19: 708-15.

14. Melby SJ, Moon MR, Lindman BR, Bailey MS, Hill LL, Damiano RJ. Impact of pulmonary hypertension on outcomes after aortic valve replacement for aortic valve stenosis. J Thorac Cardiovasc Surg. 2011;141:1424-30.

15. Barbieri A, Bursi F, Grigioni F, et al. Prognostic and therapeutic implications of pulmonary hypertension complicating degenerative mitral regurgitation due to flail leaflet: a multicenter long-term international study. Eur Heart J. 2011;32:751-9.

16. Cappola TP, Felker GM, Kao WHL, Hare JM, Baughman KL, Kasper EK. Pulmonary hypertension and risk of death in cardiomyopathy: patients with myocarditis are at higher risk. Circulation. 2002; $105: 1663-8$.

17. Miller WL, Grill DE, Borlaug BA. Clinical features, hemodynamics, and outcomes of pulmonary hypertension due to chronic heart failure with reduced ejection fraction. JACC Heart Fail. 2013;1: 290-9.

18. Simonneau G, Robbins IM, Beghetti M, et al. Updated clinical classification of pulmonary hypertension. J Am Coll Cardiol. 2009;54:S43-54.

19. Halpern SD, Taichman DB. Misclassification of pulmonary hypertension due to reliance on pulmonary capillary wedge pressure rather than left ventricular end-diastolic pressure. Chest. 2009;136:37-43.

20. Hoeper MM, Bogaard HJ, Condliffe R, et al. Definitions and diagnosis of pulmonary hypertension. J Am Coll Cardiol. 2013;62: D42-50.

21. Louie EK, Rich S, Brundage BH. Doppler echocardiographic assessment of impaired left ventricular filling in patients with right ventricular pressure overload due to primary pulmonary hypertension. J Am Coll Cardiol. 1986;8:1298-306. 
22. Ha J-W, Choi D, Park S, et al. Determinants of exercise-induced pulmonary hypertension in patients with normal left ventricular ejection fraction. Heart Br Card Soc. 2009;95:490-4.

23. Enriquez-Sarano M, Rossi A, Seward JB, Bailey KR, Tajik AJ. Determinants of pulmonary hypertension in left ventricular dysfunction. J Am Coll Cardiol. 1997;29:153-9.

24. Tumminello G, Lancellotti P, Lempereur M, D'Orio V, Pierard LA. Determinants of pulmonary artery hypertension at rest and during exercise in patients with heart failure. Eur Heart J. 2007;28:569-74.

25. Arkles JS, Opotowsky AR, Ojeda J, et al. Shape of the right ventricular Doppler envelope predicts hemodynamics and right heart function in pulmonary hypertension. Am J Respir Crit Care Med. 2011;183:268-76

26. Andersen MJ, Olson TP, Melenovsky V, Kane GC, Borlaug BA. Differential hemodynamic effects of exercise and volume expansion in people with and without heart failure. Circ Heart Fail. $2015 ; 8: 41-8$

27. Costard-Jäckle A, Fowler MB. Influence of preoperative pulmonary artery pressure on mortality after heart transplantation: testing of potential reversibility of pulmonary hypertension with nitroprusside is useful in defining a high risk group. J Am Coll Cardiol. 1992;19:48-54.

28. Klotz S, Wenzelburger F, Stypmann J, et al. Reversible pulmonary hypertension in heart transplant candidates: to transplant or not to transplant. Ann Thorac Surg. 2006;82:1770-3.

29. Beyersdorf F, Schlensak C, Berchtold-Herz M, Trummer G. Regression of "fixed" pulmonary vascular resistance in heart transplant candidates after unloading with ventricular assist devices. J Thorac Cardiovasc Surg. 2010;140:747-9.

30. Goland S, Czer LSC, Kass RM, et al. Pre-existing pulmonary hypertension in patients with end-stage heart failure: impact on clinical outcome and hemodynamic follow-up after orthotopic heart transplantation. J Heart Lung Transpl Off Publ Int Soc Heart Transpl. 2007;26:312-8.

31. Lepore JJ, Dec GW, Zapol WM, Bloch KD, Semigran MJ. Combined administration of intravenous dipyridamole and inhaled nitric oxide to assess reversibility of pulmonary arterial hypertension in potential cardiac transplant recipients. J Heart Lung Transpl Off Publ Int Soc Heart Transpl. 2005;24:1950-6.

32. Pamboukian SV, Carere RG, Webb JG, et al. The use of milrinone in pre-transplant assessment of patients with congestive heart failure and pulmonary hypertension. J Heart Lung Transpl Off Publ Int Soc Heart Transpl. 1999;18:367-71.

33. Bocchi EA, Bacal F, Auler Júnior JO, Carmone MJ, Bellotti G, Pileggi F. Inhaled nitric oxide leading to pulmonary edema in stable severe heart failure. Am J Cardiol. 1994;74:70-2.

34. Kirklin JK, Naftel DC, Kirklin JW, Blackstone EH, White-Williams C, Bourge RC. Pulmonary vascular resistance and the risk of heart transplantation. J Heart Transpl. 1988;7:331-6.

35.• Vachiéry J-L, Adir Y, Barberà JA, et al. Pulmonary hypertension due to left heart diseases. J Am Coll Cardiol. 2013;62:D100-8. Up to date consensus statement, including the recently proposed classification system for PH-LHD.

36. Naeije R, Vachiery J-L, Yerly P, Vanderpool R. The transpulmonary pressure gradient for the diagnosis of pulmonary vascular disease. Eur Respir J. 2013;41:217-23.

37. Provencher S, Hervé P, Sitbon O, Humbert M, Simonneau G, Chemla D. Changes in exercise haemodynamics during treatment in pulmonary arterial hypertension. Eur Respir J. 2008;32:393-8.

38. Gerges C, Gerges M, Lang MB, et al. Diastolic pulmonary vascular pressure gradient: a predictor of prognosis in "out-ofproportion" pulmonary hypertension. Chest. 2013;143:758-66. Describes the utility of the diastolic pulmonary gradient for identifying Cpc-PH.
39. Hemmings HC, Hopkins PM, editors. Foundations of anaesthesia: basic sciences for clinical practice. 2nd ed. Philadelphia: Elsevier Mosby; 2006.

40. Enson Y, Wood JA, Mantaras NB, Harvey RM. The influence of heart rate on pulmonary arterial-left ventricular pressure relationships at end-diastole. Circulation. 1977;56:533-9.

41. Her C, Cerabona T, Baek S-H, Shin S-W. Increased pulmonary venous resistance in morbidly obese patients without daytime hypoxia: clinical utility of the pulmonary artery catheter. Anesthesiology. 2010;113:552-9.

42. Sibbald WJ, Paterson NA, Holliday RL, Anderson RA, Lobb TR, Duff JH. Pulmonary hypertension in sepsis: measurement by the pulmonary arterial diastolic-pulmonary wedge pressure gradient and the influence of passive and active factors. Chest. 1978;73: $583-91$.

43. Tampakakis E, Leary PJ, Selby VN, et al. The diastolic pulmonary gradient does not predict survival in patients with pulmonary hypertension due to left heart disease. JACC Heart Fail. 2015;3:9-16.

44. Tedford RJ, Beaty CA, Mathai SC, et al. Prognostic value of the pre-transplant diastolic pulmonary artery pressure-to-pulmonary capillary wedge pressure gradient in cardiac transplant recipients with pulmonary hypertension. J Heart Lung Transpl Off Publ Int Soc Heart Transpl. 2014;33:289-97.

45. Selby VN, Teuteberg JJ, AllenIE, Tedford RJ, Kormos RL, De Marco T. Characterization and impact of pulmonary hypertension on outcomes after left ventricular assist device implantation. J. Heart Lung Transpl. 34;4 S142.

46. Semler HJ, Shepherd JT, Wood EH. The role of vessel tone in maintaining pulmonary vascular resistance in patients with mitral stenosis. Circulation. 1959;19:386-94.

47. Braunwald E, Braunwald NS, Ross J, Morrow AG. Effects of mitral-valve replacement on the pulmonary vascular dynamics of patients with pulmonary hypertension. N Engl J Med. 1965;273: $509-14$.

48. Silver K, Aurigemma G, Krendel S, Barry N, Ockene I, Alpert J. Pulmonary artery hypertension in severe aortic stenosis: incidence and mechanism. Am Heart J. 1993;125:146-50.

49. Malouf JF, Enriquez-Sarano M, Pellikka PA, et al. Severe pulmonary hypertension in patients with severe aortic valve stenosis: clinical profile and prognostic implications. J Am Coll Cardiol. 2002;40:789-95.

50. Luçon A, Oger E, Bedossa M, et al. Prognostic implications of pulmonary hypertension in patients with severe aortic stenosis undergoing transcatheter aortic valve implantation: study from the FRANCE 2 registry. Circ Cardiovasc Interv. 2014;7:240-7.

51. Sinning J-M, Hammerstingl C, Chin D, et al. Decrease of pulmonary hypertension impacts on prognosis after transcatheter aortic valve replacement. Euro Intervention J Eur Collab Work Group Interv Cardiol Eur Soc Cardiol. 2014;9:1042-9.

52. Zimpfer D, Zrunek P, Roethy W, et al. Left ventricular assist devices decrease fixed pulmonary hypertension in cardiac transplant candidates. J Thorac Cardiovasc Surg. 2007;133:689-95.

53. Haft J, Armstrong W, Dyke DB, et al. Hemodynamic and exercise performance with pulsatile and continuous-flow left ventricular assist devices. Circulation. 2007;116:I8-15.

54. Patel ND, Weiss ES, Schaffer J, et al. Right heart dysfunction after left ventricular assist device implantation: a comparison of the pulsatile HeartMate I and axial-flow HeartMate II devices. Ann Thorac Surg. 2008;86:832-40. discussion 832-840.

55. Torre-Amione G, Southard RE, Loebe MM, et al. Reversal of secondary pulmonary hypertension by axial and pulsatile mechanical circulatory support. J Heart Lung Transpl Off Publ Int Soc Heart Transpl. 2010;29:195-200.

56. Alba AC, Rao V, Ross HJ, et al. Impact of fixed pulmonary hypertension on post-heart transplant outcomes in bridge-to-transplant 
patients. J Heart Lung Transpl Off Publ Int Soc Heart Transpl. 2010;29:1253-8.

57. Gupta S, Woldendorp K, Muthiah K, et al. Normalisation of haemodynamics in patients with end-stage heart failure with continuous-flow left ventricular assist device therapy. Heart Lung Circ. 2014;23:963-9.

58. Califf RM, Adams KF, McKenna WJ, et al. A randomized controlled trial of epoprostenol therapy for severe congestive heart failure: The Flolan International Randomized Survival Trial (FIRST). Am Heart J. 1997;134:44-54.

59. Givertz MM, Colucci WS, LeJemtel TH, et al. Acute endothelin a receptor blockade causes selective pulmonary vasodilation in patients with chronic heart failure. Circulation. 2000;101:2922-7.

60. Packer M, McMurray J, Massie BM, et al. Clinical effects of endothelin receptor antagonism with bosentan in patients with severe chronic heart failure: results of a pilot study. J Card Fail. 2005;11:12-20.

61. McMurray JJV, Teerlink JR, Cotter G, et al. Effects of tezosentan on symptoms and clinical outcomes in patients with acute heart failure: the VERITAS randomized controlled trials. JAMA J Am Med Assoc. 2007;298:2009-19.

62. Anand I, McMurray J, Cohn JN, et al. Long-term effects of darusentan on left-ventricular remodelling and clinical outcomes in the EndothelinA Receptor Antagonist Trial in Heart Failure (EARTH): randomised, double-blind, placebo-controlled trial. Lancet. 2004;364:347-54.

63. Lüscher TF, Enseleit F, Pacher R, et al. Hemodynamic and neurohumoral effects of selective endothelin A (ET(A)) receptor blockade in chronic heart failure: the Heart Failure ET(A) Receptor Blockade Trial (HEAT). Circulation. 2002;106:2666-72.

64. Galiè N, Ghofrani HA, Torbicki A, et al. Sildenafil citrate therapy for pulmonary arterial hypertension. N Engl J Med. 2005;353: 2148-57.

65. Alaeddini J, Uber PA, Park MH, Scott RL, Ventura HO, Mehra MR. Efficacy and safety of sildenafil in the evaluation of pulmonary hypertension in severe heart failure. Am J Cardiol. 2004;94: 1475-7.

66. Lewis GD, Shah R, Shahzad K, et al. Sildenafil improves exercise capacity and quality of life in patients with systolic heart failure and secondary pulmonary hypertension. Circulation. 2007;116: $1555-62$.
67. Cooper TJ, Guazzi M, Al-Mohammad A, et al. Sildenafil in Heart Failure (SilHF). An investigator-initiated multinational randomized controlled clinical trial: rationale and design. Eur J Heart Fail. 2013;15:119-22.

68. Guazzi M, Vicenzi M, Arena R, Guazzi MD. Pulmonary hypertension in heart failure with preserved ejection fraction: a target of phosphodiesterase-5 inhibition in a 1-year study. Circulation. 2011;124:164-74.

69. Redfield MM, Chen HH, Borlaug BA, et al. Effect of phosphodiesterase-5 inhibition on exercise capacity and clinical status in heart failure with preserved ejection fraction: a randomized clinical trial. JAMA. 2013;309:1268-77. The largest published trial to date of PDE-5 inhibitors in heart failure. Of note, there were no enrollment criteria related to presence of pulmonary hypertension.

70. Tedford RJ, Hemnes AR, Russell SD, et al. PDE5A inhibitor treatment of persistent pulmonary hypertension after mechanical circulatory support. Circ Heart Fail. 2008;1:213-9.

71. Klodell CT, Morey TE, Lobato EB, et al. Effect of sildenafil on pulmonary artery pressure, systemic pressure, and nitric oxide utilization in patients with left ventricular assist devices. Ann Thorac Surg. 2007;83:68-71. discussion 71.

72. Stasch J-P, Pacher P, Evgenov OV. Soluble guanylate cyclase as an emerging therapeutic target in cardiopulmonary disease. Circulation. 2011;123:2263-73.

73. Ghofrani H-A, Galiè N, Grimminger F, et al. Riociguat for the treatment of pulmonary arterial hypertension. N Engl J Med. 2013;369:330-40.

74. Ghofrani H-A, D'Armini AM, Grimminger F, et al. Riociguat for the treatment of chronic thromboembolic pulmonary hypertension. N Engl J Med. 2013;369:319-29.

75. Bonderman D, Pretsch I, Steringer-Mascherbauer R, et al. Acute hemodynamic effects of riociguat in patients with pulmonary hypertension associated with diastolic heart failure (DILATE-1): a randomized, double-blind, placebo-controlled, single-dose study. Chest. 2014;146:1274-85.

76. Bonderman D, Ghio S, Felix SB, et al. Riociguat for patients with pulmonary hypertension caused by systolic left ventricular dysfunction: a phase IIb double-blind, randomized, placebo-controlled, dose-ranging hemodynamic study. Circulation. 2013;128:502-11. 